nopoly Committee of Ukraine of 12 October 2017 № 10-pп. URL: https://zakon.rada.gov.ua/laws/show/z1364-17\#Text.

8. Explanatory note to the draft of the Order of the Antimonopoly Committee of Ukraine «On approval of the Typical requirements for vertical concerted actions of undertakings regarding the supply and use of goods which observance allows to carry out these concerted actions without the permission of the bodies of the Antimonopoly committee of Ukraine». URL: http://www.amc.gov.ua/amku/doccatalog/document?id=136109

9. Typical requirements for concerted actions of undertakings for general exemption from prior approval from bodies of the Antimonopoly Committee on concerted actions of undertakings : Order of the Antimonopoly Committee of Ukraine of 12 February 2002 №27-p. URL: https://zakon.rada.gov.ua/ laws/show/z0239-02\#Text.

10. The Treaty on the Functioning of the European Union. OJ C 326, 26/10/2012. P. 0001-0390. URL: https://eur-lex.europa.eu/ legal-content/EN/TXT/?uri=CELEX:12012E/TXT.

11. Kravtsova I. Economic competition as an object of administrative regulation. Entrepreneurship, Economy and Law. 2020. №6. P. 149-155. URL: http://pgp-journal.kiev.ua/archive/2020/6/27.pdf

DOI https://doi.org/10.30525/978-9934-26-074-2-35

\title{
ЕЛЕКТРОННІ РАХУНКИ З ПОДАТКУ НА ДОДАНУ ВАРТІСТЬ: ПРОБЛЕМНІ ПИТАННЯ ТА ШЛЯХИ ВИРІШЕННЯ
}

\author{
Логвин А. В. \\ доктор філософії з права
}

Основне завдання системи адміністрування податків полягає у забезпеченні якісного обліку платників податків, повноти та своєчасності надходжень податкових платежів до бюджетної системи згідно 3 вимогами чинного законодавства. При цьому ефективність адміністрування досягається за рахунок ії належного нормативного закріплення та правового підгрунтя відповідних положень.

В свою чергу, головна юридична проблематика податкової сфери полягає переважно у визначенні та ефективному забезпеченні меж свободи й необхідності у поведінці суб'єктів податкових правовідносин через відповідні правові, законодавчі норми, у захисті права власності окремих платників та інтересів суспільства, які реалізуються у фінансово-податковій діяльності держави. 
Вимоги сучасності та розвиток інформаційних технологій передбачає ï широке впровадження в механізми державного (владного) управління та сприяє виникненню нових економічних та юридичних відносин, в тому числі в частині справляння податків і зборів, зокрема, запровадження електронного адміністрування податків, насамперед податку на додану вартість (далі за текстом - ПДВ). На даний час на законодавчому рівні не змінились нормативні акти, якими регламентується робота системи електронного адміністрування податку на додану вартість (далі за текстом - електронне адміністрування ПДВ, СЕА ПДВ), до яких відносяться Податковий кодекс України (далі за текстом Податковий кодекс) [1], Постанова Кабінету міністрів України від 29.12.2010 р. № 1246 (далі за текстом - Постанова № 1246) [2], Постанова Кабінету Міністрів України від 16.10.2014 p. № 569 (далі за текстом - Постанова № 569) [3].

Предметом правового регулювання в даному випадку виступають відносини, які виникають під час відкриття та роботи електронних рахунків (їх поповнення), реєстрації податкових накладних/розрахунків коригування, визначення податкових зобов'язань (звітність) та сплати податку на додану вартість, бюджетного відшкодування. Суб'єктами правовідносин є платники податку на додану вартість, контролюючі органи (Державна податкова служба України) (далі за текстом - ДПС України, контролюючий орган); органи казначейства (Державна казначейська служба України). Об'єктом правовідносин є не тільки кошти платників, які надходять у вигляді податку на додану вартість до бюджету та поповнення електронних рахунків, а й права і дії щодо електронних рахунків (відкриття, закриття та операцій на них (поповнення грошовими коштами та повернення грошових коштів) та реєстрації податкових накладних (реєстраційний ліміт).

Електронні рахунки в системі електронного адміністрування ПДВ (далі за текстом - електронні рахунки) по-перше: $є$ складовою СЕА ПДВ. По-друге: призначені для ведення обліку суми податку на додану вартість (реєстраційний ліміт), на яку платник податку може зареєструвати податкові накладні під час продажу товарів (послуг). Враховують суми ПДВ (показники) за отриманими податковими накладними або коштів, самостійно перерахованих платником (як поповнення для збільшення реєстраційного ліміту). Також, за допомогою електронного рахунку проводяться розрахунки з бюджетом. Доречним буде звернути увагу на те, що Податковим кодексом не заборонена сплата ПДВ до відповідного бюджету з поточного рахунку платника податку, відкритого в установі банку. 
На перший погляд все дуже просто, є електронній рахунок в СЕА ПДВ, який містить інформацію щодо суми ПДВ (реєстраційний ліміт), на яку платник податку може зареєструвати податкові накладні. За необхідності збільшення реєстраційної суми (ії недостатність з урахуванням отриманих податкових накладних) передбачена можливість його поповнення, в тому числі можливість поповнення для зарахування коштів в рахунок сплати поточних грошових зобов'язань з ПДВ. Доречно звернути увагу, що у разі поповнення грошовими коштами електронного рахунку для збільшення реєстраційного ліміту, подальша реєстрація податкових накладних призводить до його зменшення, тобто кошти списуються на відповідні рахунки державного бюджету (не можуть бути повернуті платнику). У разі наявності надміру сплачених грошових зобов'язань також можна повернути ці кошти на поточний рахунок використовуючи все той же електронний рахунок та податкову звітність.

Водночас, $є$ проблемні питання як технічного так i правового характеру щодо роботи з електронними рахунками в СЕА ПДВ. Так, наприклад мають місце випадки коли:

1. Платник податку має надміру сплачені грошові зобов'язанння 3 ПДВ, які були перераховані до бюджету з поточного рахунку платника в установі банку. В такому випадку, з урахуванням норм чинного законодавства платник може скористатись своїм правом і подати заяву на повернення надміру сплачених грошових зобов'язань. На підставі отриманої заяви контролюючим органом формуються відповідні реєстри, які в подальшому передаються до Держказначейства. Після чого такі кошти будуть повернуті платнику податку виключно на електронний рахунок в СЕА ПДВ. Знов ж таки звертаємо увагу, що для контролюючого органу не має значення яким чином вони були сплачені (перераховані) до бюджету 3 електронного рахунку чи 3 поточного рахунку платника податку. В подальшому, лише після надходження їх на електронний рахунок, платник може повернути такі кошти на свій поточний рахунок в установі банку подавши разом із податковою звітністю заяву (додаток 4) [4], у якій зазначити суму податку, яка підлягає поверненню.

2. Контрагентом (Покупцем) за вже поставлений товар, або який буде поставлений в майбутньому, перераховані кошти. Однак, у зв'язку із допущеною технічною помилкою під час здійснення платежу, такі кошти перераховані (надійшли) на електронний рахунок в СЕА ПДВ платника податку (Постачальника). Звісно платник податку, на електронний рахунок якого надійшли такі кошти, 3 урахуванням вимог чинного законодавства може повернути такі кошти на свій поточний рахунок в установі банку подавши разом із податковою звітністю відповідну заяву (додаток 4) [4]. А вже потім повернути їх контрагенту. 
В чому полягає схожість проблемних питань технічного та правового характеру на перший погляд двох абсолютно різних ситуацій. По-перше: в обох випадках кошти які надійшли на електронний рахунок не збільшать реєстраційний ліміт [5]. По-друге: у разі їх списання (перерахування) 3 електронного рахунку на поточний рахунок платника податку реєстраційний ліміт буде зменшено на суму, яка перераховується з електронного рахунку на поточний. В даному випадку маємо ситуацію, з огляду на технічні недоліки роботи СЕА ПДВ, які також неврегульовані з правової точки зору, за яких платник податку втрачає право на реєстраційний ліміт (у зв'язку із його необгрунтованим зменшенням (показник $\left.\sum_{\text {Попрах }}\right)$ ) [1] [3].

Необхідним є внесення змін до нормативно-правових актів, якими регламентоване правове регулювання роботи системи електронного адміністрування податку на додану вартість, а також внесення змін до програмного забезпечення, якими удосконалити алгоритм роботи CEA ПДВ. Вказаними змінами передбачити врегулювання наступних питань:

- кошти, які надходять на електронний рахунок (незалежно від джерела їх надходження, в тому числі повернення з бюджету надміру сплачених грошових зобов'язань), повинні збільшувати реєстраційний ліміт, або не зменшувати його, у разі їх подальшого повернення на поточний рахунок платника податку;

- визначення (врегулювання правових прогалин) механізму повернення коштів, помилково перерахованих на електронний рахунок 3 непоточного рахунку платника податку, або коштів, які помилково надійшли на електронний рахунок платника податку від інших платників. За можливості усунути недоліки в алгоритмі роботи CEA ПДВ та передбачити автоматичне блокування (зарахування на відповідні транзитні рахунки як нез'ясовані) та/або автоматичне повернення Держказначейством коштів, які перераховуються на електронний рахунок не з поточного рахунку такого платника.

В реаліях сьогодення, 3 правової точки зору платнику податку (власнику електронного рахунка) після встановлення факту помилкового надходження коштів на електронний рахунок від інших суб'єктів господарювання бажано:

- отримати необхідні підтверджуючі документи щодо помилковості зарахування коштів на електронний рахунок (листи від контрагентів та ін.);

- звернутись до Держказначейства та ДПС України 3 проханням здійснити повернення помилково зарахованих коштів та отримати відповідь (на даний час на жаль вона буде негативною);

- звернутись 3 адміністративним позовом до суду з відповідними вимогами до Держказначейства та органів ДПС України. За можливості 
залучити стороною по справі суб’єкта господарювання (контрагента), вимогою якого може бути визнання неправомірними дій Держказначейства щодо зарахування коштів на електронний рахунок іншого платника податків.

\title{
Література:
}

1. Податковий кодекс України : Закон України від 02.12.2010 p. № 2755-VI. URL: https://zakon.rada.gov.ua/laws/show/2755-17\#Text (дата звернення 28.02.2021).

2. Про затвердження порядку ведення Сдиного реєстру податкових накладних. : Постанова Кабінету Міністрів України від 29.12.2010 р. № 1246. URL: https://zakon.rada.gov.ua/laws/show/1246-2010-\%D0\% BF\#Text (дата звернення 28.02.2021).

3. Деякі питання електронного адміністрування податку на додану вартість: Постанова Кабінету Міністрів України від 16.10.2014 р. № 569. URL: https://zakon.rada.gov.ua/laws/show/569-2014-\%D0\%BF\#Text (дата звернення 28.02.2021).

4. Про затвердження форм та Порядку заповнення i подання податкової звітності з податку на додану вартість: Наказ Міністерства фінансів України від 28.01.2016 р. № 21. URL: https://zakon.rada.gov.ua/ laws/show/z0159-16\#Text (дата звернення 28.02.2021).

5. Загальнодоступний інформаційно-довідковий ресурс. URL: http:// zir.sfs.gov.ua/main/bz/view/?src=ques (дата звернення 28.02.2021).

DOI https://doi.org/10.30525/978-9934-26-074-2-36

\section{МІГРАЦІЙНИЙ КОНТРОЛЬ ЯК СПОСІБ ПРОТИДІЇ НЕЛЕГАЛЬНІЙ МІГРАЦІї}

\author{
Олефір В. I. \\ доктор юридичних наук, професор, \\ професор кафедри публічного права \\ Інституту управління і права \\ Національного юридичного університету імені Ярослава Мудрого \\ м. Київ, Украӥна \\ Шлях широкомасштабних реформ, обраний Україною 3 метою \\ розбудови незалежності, демократії та проєвропейського розвитку \\ обумовлює суттєву зміну управлінських відносин в державі, удоско- \\ налення правового регулювання.
}

